\title{
COMPARATIVE EVALUATION OF QTC INTERVAL CHANGES WITH INTRAVENOUS ONDANSETRON AND PALONOSETRON IN PATIENTS UNDERGOING LAPROSCOPIC CHOLECYSTECTOMY
}

\author{
Anju Jamwal ${ }^{1}$, Renu Wakhloo ${ }^{2}$, Rajdeep Kour 3 , Smiti Gulati ${ }^{4}$
}

\section{HOW TO CITE THIS ARTICLE:}

Anju Jamwal, Renu Wakhloo, Rajdeep Kour, Smiti Gulati. "Comparative Evaluation of QTc Interval Changes with Intravenous Ondansetron and Palonosetron in Patients Undergoing Laproscopic Cholecystectomy". Journal of Evolution of Medical and Dental Sciences 2015; Vol. 4, Issue 48, June 15; Page: 8375-8381,

DOI: $10.14260 /$ jemds/2015/1214

ABSTRACT: Post-operative nausea and vomiting (PONV) is a common and distressing symptom after surgery performed under general anesthesia. $5 \mathrm{HT}_{3}$ antagonists are routinely used for PONV but are dreaded to cause QTc interval prolongation. The aim of our study was to compare the incidence of QTc interval prolongation and quantify the amount of QTc prolongation from the baseline value with IV ondansetron and Palonosetron when given for PONV prevention. 60 patients undergoing elective laproscopic surgery for cholelithiasis were randomly divided into 2 groups of 30 patients each and received $4 \mathrm{mg}$ of Ondansetron and $0.075 \mathrm{mg}$ of Palonosetron intravenously respectively before induction of anesthesia. Intraoperatively serial ECG was recorded at various intervals $0 \mathrm{~min}, 3 \mathrm{~min}$, $15 \mathrm{~min}, 1 \mathrm{hr}$ and $2 \mathrm{hrs}$ along with other routine monitoring and QTc was calculated in secs by Bazett Formula. RESULTS: The QTc interval was prolonged in Ondansetron group at all-time intervals as compared to Palonosetron group where prolongation was observed only at 3 min though this difference was statistically insignificant $(\mathrm{P}>0.05)$. The difference between Ondansetron and Palonosetron group was comparable.

KEYWORDS: PONV, QTc, Ondansetron, Palonosetron.

INTRODUCTION: Post-operative nausea and vomiting (PONV) is most common and distressing concern after surgery performed under general anaesthesia effecting as many as one third of such patients. It is one of the main complaints after laparoscopy $\left(40-75 \%\right.$ of patients) ${ }^{[1]}$ and the most important factor determining the length of hospital stay after ambulatory anaesthesia thereby increasing hospital cost per patient. ${ }^{[2]}$

Overall incidence of PONV has been reported to be between $20 \%$ and $30 \%$ but can increase upto $80 \%$ in patients who are at high risk for PONV.[3]

PONV is defined as nausea, retching and vomiting occurring during first 24-48hrs after surgery, the three symptoms may occur separately or in combination.[4]

The causes of PONV are multifactorial and can largely be categorized as patient risk factors, anaesthetic technique, and surgical procedure.

Antiemetics work on several different receptor sites ${ }^{[5]}$ to prevent or treat PONV. Traditional antiemetics like Anticholinergics (Scopolamine, Atropine) Antihistaminics (Dimenhydranates), Phenothiazines (Promethazine), Butyrophenones (Droperidol, Haloperidol) and Benzamides (Metoclopramide) are used for control of PONV. Some of these are associated with high incidence of adverse effects such as restlessness, dryness of mouth, sedation, hypotension, extrapyramidal symptoms and dystonic effects. 


\section{ORIGINAL ARTICLE}

$5 \mathrm{HT}_{3} \mathrm{R}$ antagonists, ondansetron and palonosetron, are routinely used for PONV because of their safety and efficacy but these drugs are known to produce multiple effects on ECG particularly on QTc (corrected QT) interval.[6] Prophylactic palonosetron $0.075 \mathrm{mg}$ i/v is considered to be more effective than ondansetron $8 \mathrm{mg}$ i/v for prevention of PONV.[7]

Drug induced prolongation of QTc interval has become the first cause of withdrawal or restricted use of the drug in the past years because of potential risk of life threatening polymorphic ventricular tachycardia and torsades de pointes. ${ }^{[8]}$

AIM AND OBJECTIVES: To compare the incidence of QTc prolongation from the baseline and to quantify the amount of QTc prolongation with intravenous Ondansetron and Palonosetron

\section{MATERIAL AND METHODS:}

- The study was conducted in Dept. of Anaesthesiology and ICU, GMC Jammu.

- After obtaining approval from institutional ethics committee and informed written consent from the patients, 60 female patients in the age group 25-55 yrs, ASA grade-I or II having average built who were to und ergo laproscopic cholecystectomy were enrolled.

Exclusion Criteria: The following criteria were used for excluding patients from the present study;

- Baseline prolonged QTc interval.

- Patients with arrhythmias or conduction defects.

- Patients with electrolyte imbalances.

- Congenital QTc syndrome.

\section{Technique:}

- History, examination and relevant investigations were carried out.

- Preanaesthetic preparation was done and patient was kept fasting for 8hrs.

- I/V line with ringer lactate was started in OT and monitors were attached for minimal basic monitoring

- After obtaining baseline ECG, study medication was given 3 min before induction:

GROUP 0: Patients received Inj. Ondansetron $4 \mathrm{mg} \mathrm{I} / \mathrm{V}$ and,

GROUP P: Patients received Inj. Palonosetron 0.075mg I/V and simultaneously patients were pre oxygenated.

- Induction with Injection Propofol $2 \mathrm{mg} / \mathrm{kg}$ i/v, Injection Tramadol $1 \mathrm{mg} / \mathrm{kg} \mathrm{i} / \mathrm{v}$ and Injection Atracurium Besylate $0.5 \mathrm{mg} / \mathrm{kg}$ i $/ \mathrm{v}$ to facilitate tracheal intubation.

- Maintenance of general anaesthesia was done with 02+N20 (40:60) and top-up doses of injection Atracurium Besylate $0.1 \mathrm{mg} / \mathrm{kg}$.

- Intraoperative monitoring was done by monitoring HR, SBP, DBP, MAP, ETCO2 and SPO2.

- After obtaining baseline ECG, continuous ECG was observed for any changes and recording of lead-II was done with Life-Pak 20- defibrillator monitor at $0 \mathrm{~min}, 3 \mathrm{~min}, 15 \mathrm{~min}, 1 \mathrm{hr}$ and $2 \mathrm{hr}$ interval.

- QTc was calculated by using Bazett formula. 


\section{ORIGINAL ARTICLE}

$$
Q T c B=\frac{Q T}{\sqrt{R R}}
$$

- QTc is said to be prolonged when value exceeds $470 \mathrm{~ms}$ in female but we measured prolongation from the baseline ( $0 \mathrm{~min})$.

- Residual effect of muscle relaxant was reversed with Injection Glycopyrrolate $10 \mathrm{mcg} / \mathrm{kg}$ and Injection Neostigmine $50 \mathrm{mcg} / \mathrm{kg}$.

STATISTICAL ANALYSIS: Statistical analysis of the data was done using student t-test and P-value using SPSS-16 software. A p value $<0.05$ was taken to be significant.

\section{OBSERVATIONS:}

\begin{tabular}{|c|c|c|c|}
\hline Group (n-30) & $\begin{array}{c}\text { Age in Years } \\
\text { Mean } \pm \text { S.D. }\end{array}$ & $\begin{array}{c}\text { Weight } \\
\text { Mean } \pm \text { S.D. }\end{array}$ & $\begin{array}{c}\text { Duration of } \\
\text { Surgery } \\
\text { Mean } \pm \text { S.D. }\end{array}$ \\
\hline Group O & $\begin{array}{c}36 \pm 10.77 \\
(25-55 \text { Years })\end{array}$ & $\begin{array}{c}57 \pm 4.6 \\
(49-67 \mathrm{Kg})\end{array}$ & $\begin{array}{c}67 \pm 13 \\
(40-90 \mathrm{Min})\end{array}$ \\
Proup P & $\begin{array}{c}38 \pm 10 \\
(23-55 \text { Years })\end{array}$ & $\begin{array}{c}56 \pm 5.6 \\
(39-65 \mathrm{Kg})\end{array}$ & $\begin{array}{c}68 \pm 15 \\
(45-90 \mathrm{Min})\end{array}$ \\
\hline $\begin{array}{c}0.704 \\
\text { NOTHING } \\
\text { SIGNIFICANT }\end{array}$ & $\begin{array}{c}0.470 \\
\text { NOTHING } \\
\text { SIGNIFICANT }\end{array}$ & $\begin{array}{c}0.743 \\
\text { SIGNIFICANT } \\
\text { SIGING }\end{array}$ \\
\hline
\end{tabular}

Table 1: Showing the Mean Age in years, Weight in kg and Duration of surgery

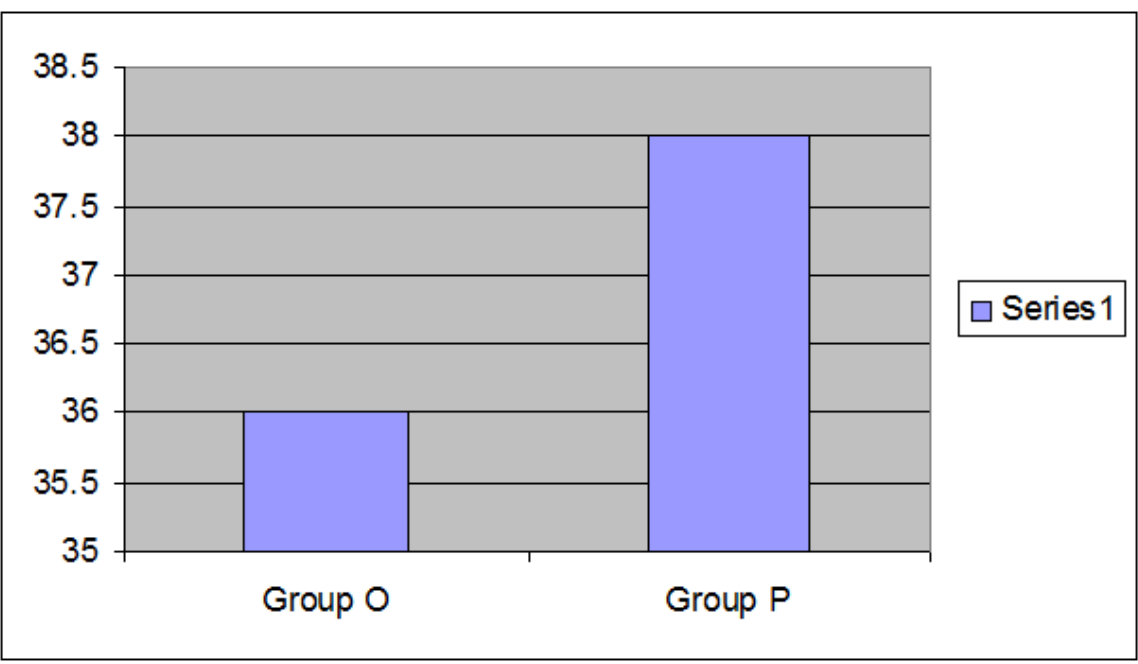

Graphical representation of mean Age in years 


\section{ORIGINAL ARTICLE}

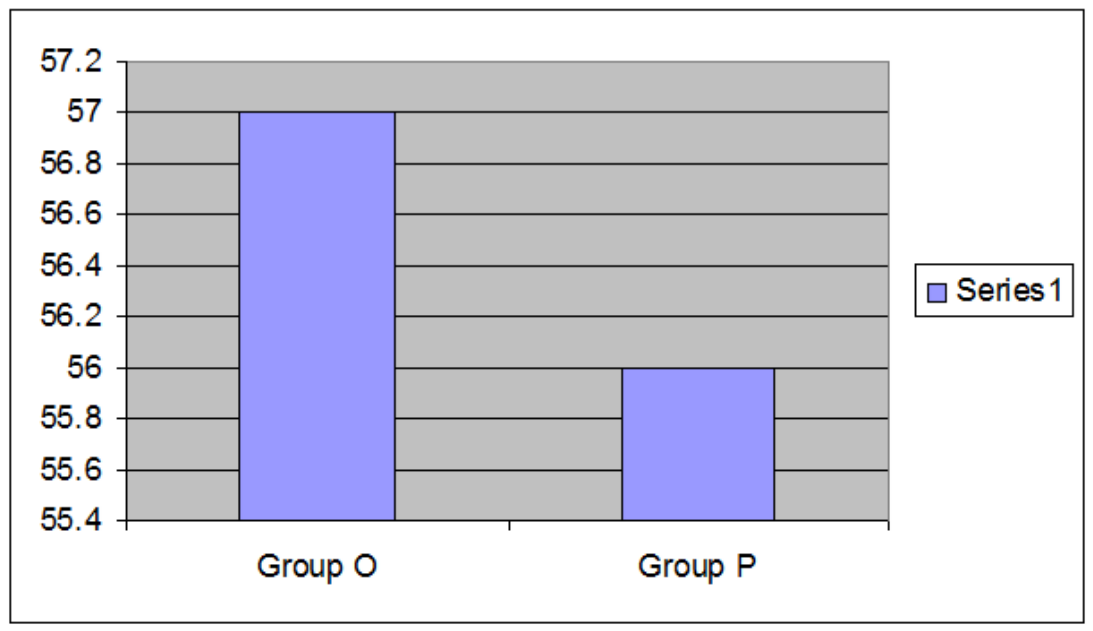

Graphical representation of mean Weight in kgs

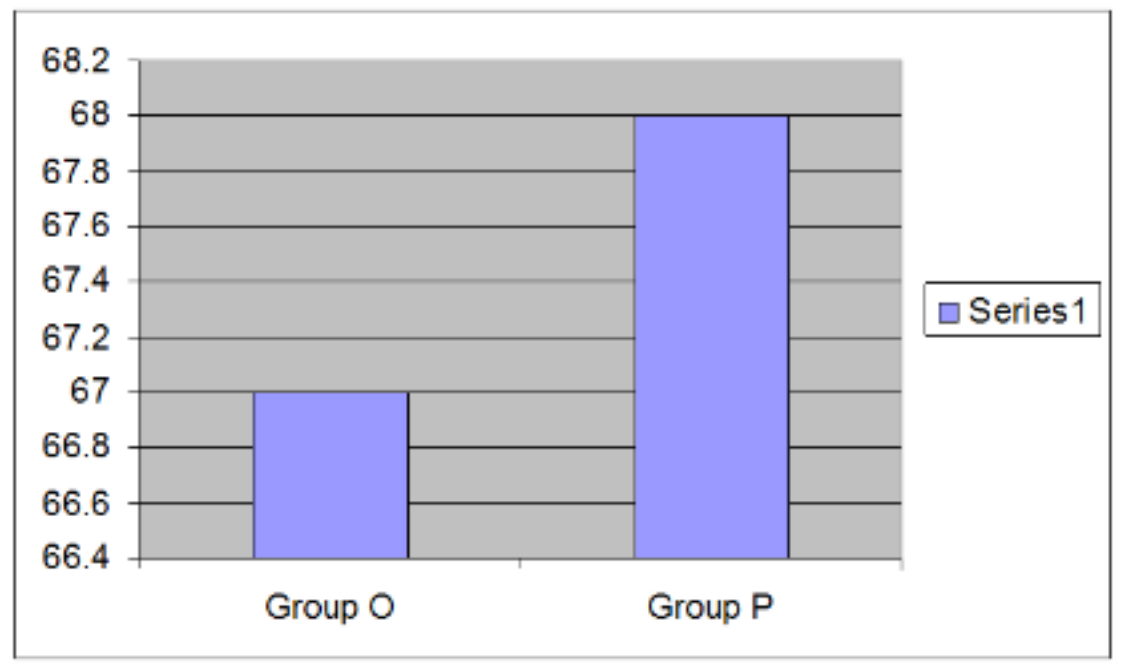

Graphical representation of mean Duration of surgery

\begin{tabular}{|c|c|c|c|c|c|}
\hline \multirow{2}{*}{$\begin{array}{c}\text { Time } \\
\text { Interval }\end{array}$} & \multicolumn{3}{|c|}{ \% of QTc interval (No. of patients) } & \multirow{2}{*}{ F value } \\
\cline { 2 - 5 } & \multicolumn{2}{|c|}{ Group O } & \multicolumn{2}{c|}{ Group P } & \\
\cline { 2 - 5 } & No & Yes & No & Yes & \\
\hline 0 min & 96 & 4 & 100 & 0 & $0.082 \mathrm{NS}$ \\
\hline $3 \mathrm{mins}$ & 92 & 8 & 96 & 4 & $0.060 \mathrm{NS}$ \\
\hline $15 \mathrm{mins}$ & 90 & 10 & 100 & 0 & $0.126 \mathrm{NS}$ \\
\hline $1 \mathrm{hr}$ & 94 & 6 & 100 & 0 & $0.168 \mathrm{NS}$ \\
\hline $2 \mathrm{hr}$ & 96 & 4 & 100 & 0 & $0.599 \mathrm{NS}$ \\
\hline
\end{tabular}

Table 2: Showing Incidence of QTc prolongation 


\section{ORIGINAL ARTICLE}

\begin{tabular}{|c|c|c|c|}
\hline TIME & $\begin{array}{c}\text { GROUP O } \\
\text { Mean } \pm S D(\text { sec })\end{array}$ & $\begin{array}{c}\text { GROUP P } \\
\text { Mean } \pm \text { SD }(\text { sec })\end{array}$ & P-VALUE \\
\hline O Min & $0.403 \pm 0.041$ & $0.401 \pm 0.036$ & $.901 \mathrm{NS}$ \\
\hline 3Min & $0.406 \pm 0.044$ & $0.404 \pm 0.027$ & $.607 \mathrm{NS}$ \\
\hline 15 Min & $0.406 \pm 0.044$ & $0.399 \pm 0.032$ & $.08 \mathrm{NS}$ \\
\hline 1Hour & $0.401 \pm 0.036$ & $0.400 \pm 0.032$ & $.129 \mathrm{NS}$ \\
\hline 2 Hour & $0.402 \pm 0.066$ & $0.400 \pm 0.032$ & $.600 \mathrm{NS}$ \\
\hline
\end{tabular}

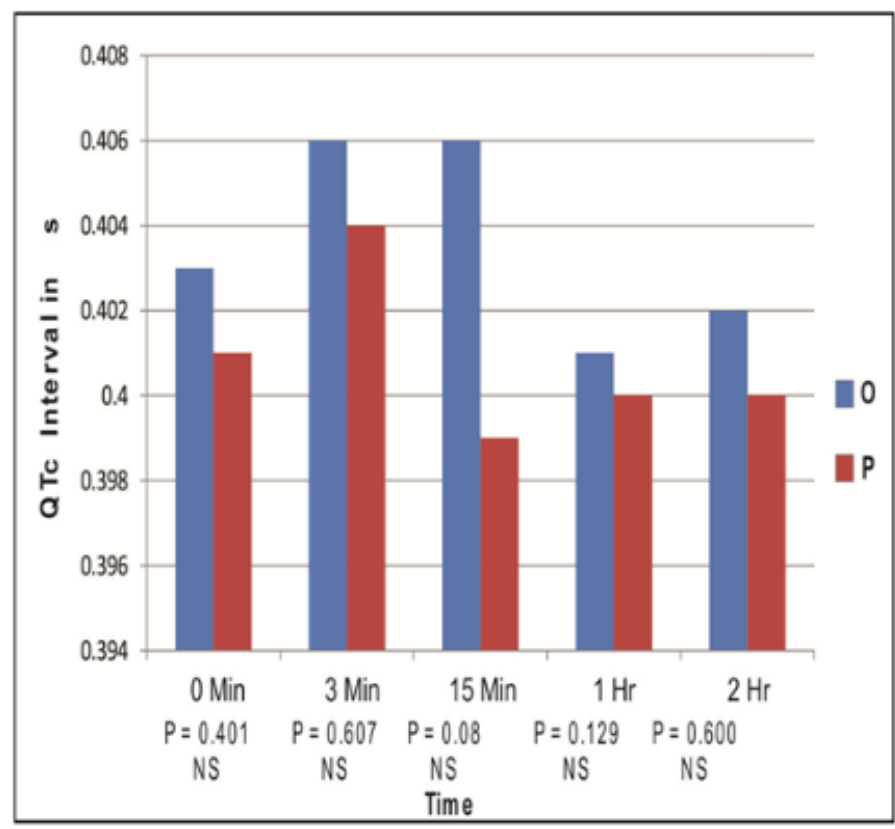

\section{Graphical representation of QTc interval changes}

DISCUSSION: The present study was conducted on 60 patients divided into 2 groups of 30 patients each, Group 0 (ondansetron group) and Group P (palonosetron group).

Results show that no statistically significant difference was observed between two groups with respect to age, weight and duration of surgery.

We observed a prolongation of QTc interval from the baseline more so in Group 0 patients where the incidence varied from $4 \%$ to $10 \%$ with the maximum incidence seen at $15 \mathrm{mins}(10 \%)$. On the contrary in Group P the incidence of patients showing prolongation from baseline was $0 \%$ at alltime intervals except at 3 mins where $4 \%$ showed a prolongation from baseline, but this difference was statistically insignificant $(\mathrm{p}>0.05)$.

In our study we found that QTc interval was prolonged at all-time intervals in ondansetron group. A prolongation of QTc in patients receiving Inj Ondansetron was also observed by Charbit et al[9] in their comparitive study between Inj. Droperidol and Inj Ondansetron. Gupta S D et al[10] observed that $1 \mathrm{mg}$ i/v ondansetron effectively prevented PONV without causing prolongation of QTc interval whereas significant QTc prolongation was noted with 4mg and 8mg ondansetron given in 
healthy adult participants. Hafermann $\mathrm{M} \mathrm{J}$ et al[11] concluded that $\mathrm{i} / \mathrm{v}$ ondansetron in doses approved by FDA can significantly prolong QTc interval leading to torsades de pointes in high risk cardiac patients. Lee et al[12] in 2014 reported that prolongation of QTc interval with Inj. Palonosetron might occur. We also observed the prolongation with palonosetron at 3 min interval though could not prove it statistically. The reason for this could be that they included patients who were concomitantly taking other drugs too, which we did not include in our study (as is cited in their article). Kim HJ et al[13] showed that preanaesthetic administration of palonosetron $(0.075 \mathrm{mg})$ did not affect the QTc interval during intraoperative period.

In our study we found that QTc interval prolongation from the baseline levels were comparable in both groups and at all intervals and in no patient QTc interval was more than $470 \mathrm{~ms}$. Navari R M et al[14] in their study reported that ECG interval changes are a class effect of 5hydroxytryptamine 3 receptor antagonists. Theoretical concern regarding cardiovascular adverse events with these agents is not supported by clinical experience. The significant benefits of these agents outweigh the theoretical small risk of meaningful cardiovascular event.

CONCLUSION: We concluded that both i.v Ondansetron and Palonosetron might induce the prolongation of corrected QT interval but the incidence was found to be more in patients who received Ondansetron. As in no patient QTc prolongation was found to be more than 470ms with these agents, the minimal risk of ECG interval changes can be ignored over the significant benefits of these in preventing PONV.

In high risk patients with cardiac disease, Palonosetron might be a safer agent. Further research work needs to be done in evaluating the efficacy in patients with already prolonged QTc interval and to consider all of the factors related to QTc prolongation, albeit caution has to be taken while using this drug in patients at high cardiac risk group and in all those medical situations which predispose to arrhythmias.

\section{REFERENCES:}

1. Ansari M M, Siddiqui O A, Haleem S, Varshney R, Akhtar S, Khan F A Comparison of ramosetron and ondansetron for control of post-operative nausea and vomiting following laproscopic cholecystectomy. Indian journal of medical sciences 2010; 64: 272-80.

2. Mansour E E. Postoperative nausea and vomiting prophylaxis: The efficacy of a novel antiemetic drug (Palonosetron) combined with Dexamethasone. Egyptian Journal of Anaesthesia 2013; 29: 117-23.

3. Apfel C C, Laara E, Koivuranta M, Greim C A, Roewer N. A Simplified Risk Score for Predicting Postoperative Nausea and Vomiting: Conclusions from Cross- validations between Two Centres. Anesthesiology 1999; 91: 693-700.

4. Pierre S, Whelan R. Nausea and vomiting after surgery Cont Edu Anaesth Crit Care \&Pain 2013; 13: 28-32.

5. Swaika S, Pal A, Chatterjee S, Saha D, Dawar N. Ondansetron, ramosetron, or palonosetron: Which is a better choice of antiemetic to prevent postoperative nausea and vomiting in patients undergoing laproscopic cholecystectomy? Anesthesia Essays and researches 2011; 5: 182-86.

6. Kuryshav Y A, Brown A M, Wang L, Benedict C R, Rampe D Interactions of 5- Hydroxytryptaine 3 antagonists class of antiemetic drugs with human cardiac ion channels. J Pharmacol Exp Ther 2000; 295: 614-20 


\section{ORIGINAL ARTICLE}

7. Singh T, Shah N, Patel C, Upadhayaya R.M. A comparative study of prophylactic ondansetron versus palonosetron for post-operative nausea and vomiting in middle ear surgeries. Internet Journal of biomed and advanced research 2014; 5: 619-22.

8. Roden DM Drug induced prolongation of the QT interval N Eng J Med 2004; 350: 1013-22.

9. Charbit B, Albaladejo P, Funck-Brentano C, Legrand M, Samain E, Marty J. Prolongation of QTc Interval after Postoperative Nausea and Vomiting Treatment by Droperidol or Ondansetron. Anesthesiology 2005; 102: 1094-100.

10. Gupta S D, Pal R, Sarkar A, Mukherjee S, Mitra K, Roy S, Sarbapalli D, Kundu K K, Zaman F A, Kar $S$ Evaluation of Ondansetron-induced QT interval prolongation in the prophylaxis of postoperative emesis. J Nat Sci Biol Med. 2011 Jan-June; 2(1): 119-24.

11. Hafermann M J, Namdar R, Seibold G E, Page RL 2nd. Effect of intravenous ondansetron on QT interval prolongation in patients with cardiovascular disease and additional risk factors for torsades: a prospective, observational study. Drug Healthc Patient Saf. 2011; 3: 53-58.

12. Lee J, In J. Effects of Palonosetron on prolongation of corrected QT intervals may be less than reliable. Korean J Anesth 2014; 66: 327-28.

13. Kim HJ, Lee HC, Jung YS, Lee J, Min JJ, Hong DM Effect of palonosetron on the QTc interval in patients undergoing sevoflurane anaesthesia. Br J Anaesth 2014; 112: 460-8.

14. Navari R M, Koeller J M Electrocardiographic and cardiovascular effects of the 5hydroxytryptamine 3 receptor antagonists. Ann pharmacother 2003; 37: 1276-86.

\section{AUTHORS:}

1. Anju Jamwal

2. Renu Wakhloo

3. Rajdeep Kour

4. Smiti Gulati

\section{PARTICULARS OF CONTRIBUTORS:}

1. Assistant Professor, Department of Anaesthesiology and ICU, GMC, Jammu.

2. Lecturer, Department of Anaesthesiology and ICU, GMC, Jammu.

3. Post Graduate Student, Department of Anaesthesiology and ICU, GMC, Jammu.

FINANCIAL OR OTHER COMPETING INTERESTS: None
4. Professor \& HOD, Department of Anaesthesiology and ICU, GMC, Jammu.

NAME ADDRESS EMAIL ID OF THE CORRESPONDING AUTHOR:

Dr. Anju Jamwal,

\# 105-f, Lower Shiv Nagar,

Behind AG Office, Jammu-180001, J \& K.

E-mail: anjujamwal3@gmail.com

Date of Submission: 21/05/2015. Date of Peer Review: 22/05/2015. Date of Acceptance: 06/06/2015. Date of Publishing: 13/06/2015. 